\title{
Board Interlocking and Firm Performance: Evidence from Indonesia
}

\author{
Meilinda Brielyan Pertiwi ${ }^{\bowtie}$, Arief Yulianto \\ Management Department, Faculty of Economics, Universitas Negeri Semarang, Semarang, Indonesia
}

\begin{tabular}{l} 
Article Information \\
\hline Article History: \\
Received January 2020 \\
Approved February 2020 \\
Published March 2020 \\
\hline Keywords: \\
Board Interlocking, Firm \\
Performance, Agency \\
Theory.
\end{tabular}

Theory.

\begin{abstract}
This study aims to determine the relationships of board interlocking and firm performance as measured by Return on Assets (ROA). This research method uses a quantitative approach with research objects of all companies listed on the Indonesia Stock Exchange period 2008-2017. The sample selection method uses a purposive sampling. The sample used was 4450 observation. Data analysis methods used are descriptive analysis and dummy variable regression Analysis of Covariance (ANCOVA). The result showed that the average performance of companies that do interlock of directors at other companies at the same time is higher than companies that do not do interlock. The existence of a director who has do interlock allows directors to get access in other places and can mutually utilize resource supported by empirical result where the total assets of companies that do interlock higher than companies that did not interlock. Although concurrent positions can improve the company, the company still complies with government regulations so that the company does not get the law and get sanctionse.
\end{abstract}

\section{INTRODUCTION}

One of the factors that affect the firm performance is interlock board of directors. According to Mizruchi (1996) when a person affiliated with one companies sits on the board of directors of another companies. Both in developed and developing countries is not infrequently a director more than one company. Interlock relationship between companies can provide influence on corporate governance interrelated (Davis, 1996). Interlock their relationship can influence policies and decisions taken a firm strategy.

The rules regarding interlock is governed by Komisi Pengawas Persaingan Usaha Republik Indonesia No. 5 of 1999 concerning Prohibition of Monopolistic Practices and Unfair Competition. One form of behavior that led to the prac- tice of monopoly is interlock. A interlock occurs when a person who served as directors or commissioners of two or more companies. This includes a interlock between the parent company, a holding company with subsidiaries other members, or subsidiaries of the various holding companies. Interlock are prohibited if the company is located in the same relevant market, has a strong bond in the field and type of business, or collectively to a market share of certain goods or services which may result in monopolistic practices and or unfair business competition.

In the condition in Indonesia is still their companies are doing interlock despite the prohibition of the Komisi Pengawas Persaingan Usaha Republik Indonesia regarding the prohibition of monopolistic practices and unfair business competition. Following the development of interlock of directors during the period 2008-2017:

(C) 2019 Universitas Negeri Semarang

\footnotetext{
Correspondence Address:

L2 Building, 1st Floor, Faculty of Economics, Universitas Negeri Semarang

Jalan Taman Siswa, Sekaran, Gunungpati, Semarang, 50229

E-mail: meilindabp08@gmail.com
} 


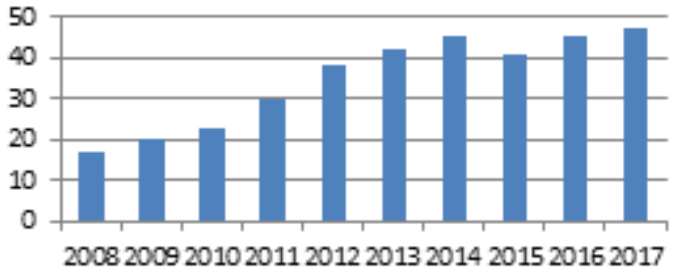

Figure 1. The number of concurrent positions of directors during the period 2008-2017

Interlock have a negative impact on the performance of the company. This is due to lack of focus, time and energy so that the board can not act as an effective agent and interlock can cause conflict of interest (Banks, 2004). Conflicts of interest can occur where the council has a strategic position in the company that has a relationship with another company that also he held.

The performance of companies represented through proxies ROA of the years 2008 until 2017 gives an unstable or fluctuating average. This is graph that indicating the average performance of companies that do interlock and didn't interlock in the period 2008-2017:

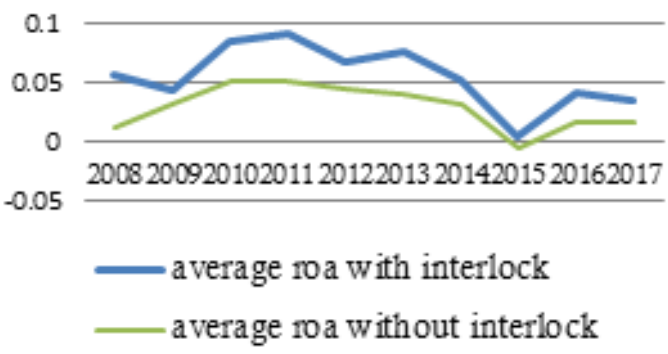

Figure 2. The average rate of the ROA do interlock and don't interlock in companies listed on the Stock Exchange in 2008-2017

Source: ICMD and Company Financial Statements Year 2008-2017

In the graph above, the movement of the average performance of companies that interlock from year to year showed a higher yield than the average performance of companies that do not interlock. It indicates contradictory to the statement that the company will produce a interlock lower performance of the company in accordance with the theory of agency by Jensen and Meckling (1976) said that the agency is assumed to work in accordance with the wishes principal or shareholder. While agents do not always behave as desired by the principal and want to maximize their personal interests. One thing that can harmful the company and its shareholders is the interlock. Agents want a high incentive so that agents will work at other companies. The agent will not always abiding by the principal but the agent will adhere to other companies so that a conflict of interest with the principal resulting in a lower performance of the company.

All aspects related to the interlock has important implications for the structure and the effective functioning of the firms, which in turn has an important role in corporate governance and corporate performance (Hermalin \& Weisbach, 2003). The influence of the interlock produced mixed results in the empirical literature. Directors who perform interlock allowing access elsewhere. There are several reasons one of which related to interlock information exchange this case refers to a variety of important information relating to new policies and practices among companies in interlock that can lead to better performance (De, 2003).

According to Roudaki and Bhuiyan (2015) directors who served many boards have the advantage that allows them to learn about different management styles and to improve their skills. Researcher Pombo and Gutiérrez (2011), Saidin et al. (2013), showed positive results between the interlock and firm performance.

But didn't rule out the presence of a greater gap between the interlock of the directors should focus on one company turns serving copies on other companies to the detriment of shareholders. It is stated in the Roadmap OJK stated that geminating several positions at once, in excess, can lead commissioners and directors are not focused and accountable in carrying out fiduciary duties that could harmful the company. In a public company, excessive interlock can also be detrimental to shareholders (Roadmap Tata Kelola Indonesia).

It was submitted Roudaki and Bhuiyan (2015) that the board of directors will be less attention to the occupied or to prefer other council in the use of time and eventually cause performance degradation on any one company. Research result Non and Franses (2007), Kaczmarek et al. (2012) Roudaki and Bhuiyan (2015), and Nam and An (2018) showed negative results between the interlock on the performance of the company.

The purpose of this study was to determine whether there are differences in the average performance of companies that do interlock and don't interlock.

\section{Hypothesis Development}

Agency theory explain the work contract carried out by the owner of the company (principal) against the manager (agent) wherein one or 
more owners do delegate tasks to managers for strategic decision making related to the operations of the company (Jensen \& Meckling, 1976).

Yulianto (2013) said that the agency theory begins with the theory of motivation of MC Gregor 1960, says there are two models of the difference in behavior and motivation among workers who are lazy and don't like working with employees who are ambitious, have a self-motivated, and selfcontrol developed (Ross, 1973). Ross (1973) states that each party seeks to develop the expected utility that will potentially lead to the agency.

According to Yulianto et al. (2014) agency relationship is the relationship between the manager as agent and the owner as well as the principal shareholder. The agency relationship is a contract whereby the principal rule the agent to perform a service on behalf of the principal and authorized agent make the best decisions for the principal. If the two sides have the same goal to maximize the value of the company, then the agent will act corresponds to the interests of the principal.

Agents are assumed to work in accordance with the wishes of shareholders. While agents do not always behave as desired by the principal and want to maximize their personal interests. One thing that can harmful the company and shareholders is the interlock. Agents want a high incentive so that agents will work at other companies. The agent will not always abiding by the principal but the agent will adhere to other companies so that a conflict of interest with the principal who in turn might lower the firm performance.

Meanwhile, if the individual holds many positions simultaneously will face severe time constraints. This was due to a greater gap between the interlock of the directors should focus on one company turns serving copies on other companies to the detriment of shareholders. Interlock could result in the implementation of some kind of time pressure on the directors which would affect the efficiency of the firm performance (Hamdan, 2018).

In addition to the interlock of directors who served as directors at other companies at the same time can be detrimental to shareholders because the directors did not focus on the work that the agency conflict with the principal increases. This is consistent with research Non and Franses (2007), Kaczmarek et al. (2012) Roudaki and Bhuiyan (2015), and Nam and An (2018) which explains the negative correlation between board interlocking and firm performance because company that do interlock can lead to the application of some kind of time pressure on the directors which will affect its efficiency in the implementation of its duties so that firm performance can decline. So that it makes the average performance of companies that interlock lower than companies that do not interlock.

$\mathrm{H} 1$ : There are differences in the average company that interlock and do not interlock.

Based on the description of the theoretical basis of the above in the literature review that has been described previously, the model framework was used to facilitate understanding of the concepts used are as follows:

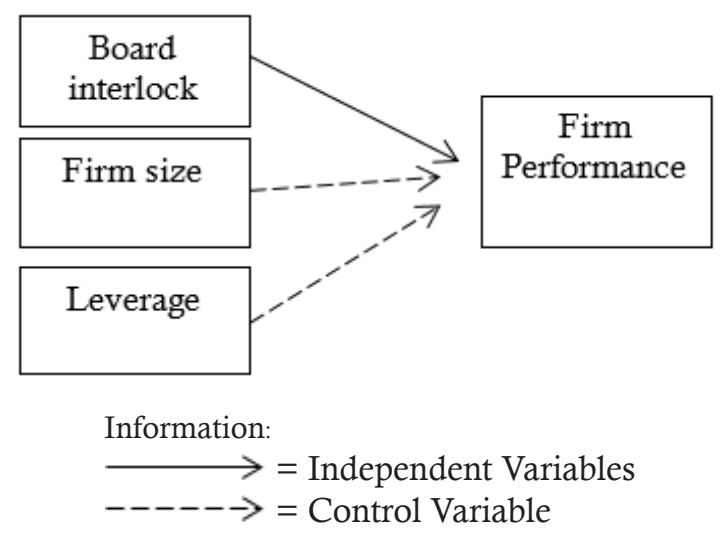

Figure 3.Research Model

\section{METHOD}

This research included explanatory research which explains the position of this study as well as the relationship between the independent variables are interlock of corporate performance through the ROA. The study uses a quantitative approach to numerical and statistical analysis using. The design study is the study of causality in which the research design is structured to examine the possibility of causal relationships between variables. Causal relationships between variables interlock as an independent variable, leverage and firm size as control variables on the performance of companies that proxied through the ROA that have been predicted by the researcher, so that researchers can declare the classification of related variables and the dependent variable causes.

The data used are unbalanced panel or panel is unbalanced because the amount of time the unit of observation is different for each of the entities or individuals. Secondary data in this study were drawn from the annual reports published by the Indonesia Stock Exchange. The sampling technique used purposive sampling based on certain criteria set by the researchers. The method used is a dum- 
my variable regression analysis with the model uses Analysis of Covariance (ANCOVA).

$$
\begin{aligned}
& \text { ROA }=\alpha+\text { Dinterlock }+\mathrm{e} \\
& \text { Information: } \\
& \text { ROA }=\text { Firm Performance } \\
& \alpha=\text { Constant } \\
& \beta_{1} \quad=\text { Coefficient of each variable } \\
& \text { Dinterlock }=\text { Dummy Interlock } \\
& \text { e } \quad=\text { The error }
\end{aligned}
$$

The dependent variable in this study is the firm performance as measured by ROA. Wijayanto (2010) ROA is used to measure the effectiveness of the company in generating profits by exploiting dimiliknya assets. ROA provide information on how efisiens companies in conducting business activities and measure the effectiveness of the company in generating profits by maximizing profits by exploiting its assets (Muliawati \& Khoiruddin, 2015). ROA reflects the greater the company's ability to generate high profits for shareholders (Wardoyo \& Veronica, 2013). According to Alghifari (2014) ROA can be calculated by: set) $\mathrm{x} 100 \%$

$\mathrm{ROA}=($ Net Income After Tax $) /($ Total As-

Independent variables used in this study is a interlock. Company said to do a interlock when one of the directors at the company's directors serving on other companies at the same time (Mizruchi, 1996). In this study, using a kind of interlock horizontally. In the regulation, the Komisi Pengawas Persaingan Usaha Republik Indonesia, Horizontal Interlocking Directorate that is where the board or a board of directors who served on two or more of the same company. Interlock is measured as a dummy variable, which is worth 1 if the company concurrent position and is 0 if not concurrently.

The control variables used in this study is the size of the company and leverage. The size of the company determine where the greater investor confidence in the company will be known to the public and easier to obtain information about the company (Haryanto, 2014). This research will take into consideration the size of the company to ensure its findings are comparable with previous studies. Determining the size of the scale of the company can be determined based upon total sales, total assets, the average level of sales (Seftianne \& Handayani, 2011)we must consider many things influencing it. The research was to analyzed the factors that influence to the capital structure companies joining the Jakarta Stock
Exchange. The sample of this research consisting of 92 data that has been listing in Indonesian Stock Exchange for the period 2007 until 2009 that has been selected by purpose sampling method. This study uses multiple regression method to see the contribution of each variable in influence capital structure. The empirical result indicates that size and growth opportunity have influence to capital structure. Other independent variables (managerial ownership, business risk, profitability, liquidity and asset structure. Measurement variables firm size, the natural logarithm of the total assets of the company (Ridhloah, 2010). To reduce the significant difference between the size of the company is too big to company size is too small, then the total value of assets formed into a natural logarithm.

$$
\text { Size }=\text { Ln (Total Assets) }
$$

Other control variables are leveraged to measure on how much the assets of debt-funded company. The higher this ratio, the greater the amount of loans used to generate corporate profits (Nugraha, 2013) debt to equity ratio, and long debt to equity ratio to company performance as measured by Economic Value Added on the Kompas 100 Index companies listed on the IDX. The sample in this study was Kompas 100 Index companies in 2009-2011, which amounted to 36 companies for three years. From the results of the study it can be seen that simultaneously DAR, DER and LDER variables have a significant effect on company EVA incorporated in the Compass 100 Index. Partially DAR and DER variables have a significant effect on EVA, whereas LDER variables have no effect on company EVA which incorporated in the Compass 100 Index. Meanwhile, according to Rahmawati and Khoiruddin (2017) financial leverage which is also measured by the debt ratio can be known whether the debt can be offset by the amount of the company's assets. Information debt ratio is also important because the lender can measure how high the risk of debt provided to the company. According to Yulianto et al. (2018) debt can be beneficial for a company to bonding and monitoring mechanisms. This research will take into consideration the size of the company to ensure its findings are comparable with previous studies. Measurement of financial leverage Hamdan (2018) using:

$$
\text { Lev }=(\text { Total Debt }) /(\text { Total Assets })
$$

The data used in this study are secondary data from company financial statements were re- 
corded in 2008-2017. The data comes from IDX financial statements, while the data is derived from the name of the board of directors ICMD tailored to the company's Annual Report. Data collection techniques in this study is documentation. Documentation used is a document published by idx.co.id in the form of BEI, ICMD, and published annual reports. The data collection was done by tabulating the names of the board of directors yamg then identified and tabulated into a database name with the help of Microsoft Excel to match the name similarity (Ahmar et al., 2016).

\section{RESULTS AND DISCUSSION}

\section{Descriptive Statistics}

Descriptive statistics provide a snapshot of the data that is seen from the average (mean), standard deviation, maximum, minimum of each variable (Ghozali \& Ratmono, 2013). Based on the analysis performed using software Eviews 9 can be seen the results of each variable nature of research. Variables used in the study of the firm performance, interlock, firm size, and leverage. Descriptive statistics of the test results obtained as follows:

Table 1.Descriptive Statistic of Companies listed on the IDX

\begin{tabular}{llll}
\hline & ROA & UP & LEV \\
\hline Mean & 0.030476 & 14.55449 & 0.600139 \\
Maximum & 3.4747 & 20.84216 & 72.7397 \\
Minimum & -9.1162 & 6.665377 & 0.000000 \\
Std. Dev. & 0.202195 & 1.912352 & 1.267685 \\
$\mathrm{~N}$ & 4450 & 4450 & 4450 \\
\hline
\end{tabular}

Source: Secondary data processed (2019)

The samples used in this study is as much as 4450 units of observation. Number of observation units to the total sample of public companies listed on the Indonesia Stock Exchange during the 10-year observation period, namely from the years 2008-2017.

The results showed that the average results of the variable performance of the company which is proxied by the ROA in the study period of 0.030476 to 0.202195 standard deviation value. The average value (mean) ROA showed smaller yield than the standard deviation, it indicates the existence of irregularities uneven because of fluctuating data dissemination. On the results of descriptive statistics ROA above the highest value of 3.4747 is the issuer ICTSI Jasa Prima Tbk (KARW) in 2011 among other public companies.
The Infrastructure, Utilities, Transport sector companies. Results of descriptive statistical analysis on public companies showed the lowest value of -9.1162 on a issuers Global Teleshop Tbk (GLOB) in 2015. The company entered the Trade, Services, Investment.

Table 2.Descriptive Statistics

\begin{tabular}{lll}
\hline Category & freq & Percentage \\
\hline Company do interlock & 348 & $7.82 \%$ \\
$\begin{array}{l}\text { The Company does not } \\
\text { interlock }\end{array}$ & 4102 & $92.18 \%$ \\
Amount & 4450 & $100 \%$ \\
\hline
\end{tabular}

Descriptive statistical test results that have been done shows frequency of 348 interlock of observation units or by $7.82 \%$ of the total units of observation, while not interlock by 4102 or by $92.18 \%$. The results showed the frequency interlock is smaller than that are not duplicates.

The average value of the size of the company is equal to 14.55449 and the value of the standard deviation to 1.912352 . Standard deviation value is smaller than the average value, it indicates that the issuer observation there is no extreme data that can lead to bias in research results or normally distributed data. Lowest firm size value is equal to 6.665377 on a issuers Fast Food Indonesia Tbk (FAST) in 2008 and a high of 20.84216 on the issuer's Bank Rakyat Indonesia (BBRI) in 2017.

The average value of leverage that is equal to 0.600139 and standard deviation value of 1.267685. Standard deviation greater than the average value, it indicates that the deviation is uneven due to fluctuating data dissemination. Value size seebesar lowest at 0:00 on a firm Mainstay Energy Sources (ITMA) 2015 and a high of 72.7397 on the company Hanson International Tbk (MYRX) in 2008.

\section{Model Regression with Dummy Variables}

Final regression model used in this study is the use Analysis of Covariance (ANCOVA). ANCOVA is a regression model that includes a combination of qualitative independent variable (dummy) and quantitative. ANCOVA model is an extension of the ANOVA models that provide statistical methods to control the influence of the independent quantitative variables is often called a control variable (Ghozali \& Ratmono, 2013). Here are the results of the regression output used in this study: 


\section{Regression Test Results}

Table 3. Regression Test Results

\begin{tabular}{lll}
\hline variable & coefficient & Prob. \\
\hline C & -0.000146 & 0.9810 \\
INTERLOCK & 0.021449 & 0.0000 \\
LEVERAGE & -0.018879 & 0.0000 \\
FIRM SIZE & 0.002744 & 0.0000 \\
\hline
\end{tabular}

From the above, the regression results obtained with the dummy variable regression model analysis of covariance in this study are as follows:

$$
=-0.000146+0.021449-0.018879 \text { LEV + }
$$
$0.002744 \mathrm{UP}+\mathrm{e}$

From the equation it can be seen the constant value of -0.000146 and double position value (Dinterlock) has a value koefieisen 0.021449. Variable interlock is categorized dummy variables which are divided into two categories. A value of 1 for companies that do interlock in other companies and a value of 0 for companies that do not interlock at other companies.

The results show that the average performance of a company that do interlock is higher than a company that don't interlock.

\section{Coefficient Determination Test (Adjusted $\mathbf{R}^{2}$ )}

Table 4. Coefficient Determination Test Results

$\begin{array}{ll} & \text { Score } \\ \text { R-squared } & 0.124075 \\ \text { Adjusted R-squared } & 0.123397\end{array}$

In Table 4. The test results of the coefficient of determination () is 0.124075 , or $12.4 \%$, which means the degree of variation of the variable performance of the company is able to be explained by the variable interlock and size of the company. The rest is equal to $87.6 \%$ explained by other variables outside the model.

Table 5. Test results for $t$ companies listed on the IDX

\begin{tabular}{lll}
\hline variable & coefficient & Prob. \\
\hline C & -0.000146 & 0.9810 \\
INTERLOCK & 0.021449 & 0.0000 \\
LEVERAGE & -0.018879 & 0.0000 \\
FIRM SIZE & 0.002744 & 0.0000 \\
\hline
\end{tabular}

Based on $t$ test calculations obtained interlock variable coefficient value of 0.021449 , t-statistic of 7.375152 and 0.0000 significance value of less than $\alpha=5 \%$. This shows that there are differences in the average performance of companies that interlock significantly so that, $\mathrm{H} 1$ is accepted.

\section{Differences in the Average Performance of the Company between companies that do interlock and don't interlock}

The hypothesis of this study is "There are differences in the average company that interlock and do not interlock". However, the interlock variable has a positive coefficient sign and the significant value of below $5 \%$. Companies that hold concurrent positions have an average performance of 0.021303 and are not interlock the average performance of -0.000146 . There are on average higher performance in companies that interlock than companies that do not interlock.

The existence of a positive relationship between the interlock with the firm performance shows that the higher the percentage of directors who concurrently hold a position in another company makes an average of the higher performance of the company. This is evidenced from the research data on the financial statements of the company code BSDE, DUTI, henna, INKP, LPPF, LMSH, MIRA, TOTL from 2008 to 2017.

At the firm performance in the year 2008-2017 a company that does concurrent positions at other companies tends to increase. The results of the study are consistent with previous hypotheses proposed in the research that there are differences in the average company that interlock and do not interlock.

It indicates the discrepancy of agency theory presented by Jensen and Meckling (1976) That the agent is assumed to work in accordance with the wishes of shareholders. While agents do not always behave as desired by the principal and want to maximize their personal interests. One thing that could harmful the company and its shareholders is the interlock. Agents want a high incentive so that agents will work at other companies. The agent will not always abiding by the principal but the agent will adhere to other companies so that a conflict of interest with the principal who in turn might lower the firm performance.

Interlock of directors who served as directors at other companies at the same time can be detrimental to shareholders because the directors did not focus on the work that the agency conflict with the principal increases. Interlock could result in the implementation of some kind of time 
pressure on the directors which would affect its efficiency in the execution of their duties so that the firm performance may decline (Hamdan, 2018). These results prove that the agency theory does not apply in Indonesia. So that a phenomenon that occurs in Indonesia, the directors who perform interlock produces an average of the high performance of the company. Therefore, this research does not match Roudaki and Bhuiyan (2015) and Nam and An (2018) with the result that interlock the company and director of a significant negative effect on the performance of the company.

Directors at companies that perform concurrent positions at other companies have an average ROA higher than those without concurrent positions can be assumed that interlock their firms allow directors to gain access elsewhere. This shows the interlock can have access to sources of knowledge, ideas, and capital of another company (Hermalin \& Weisbach, 2003). Directors who served as directors in other companies are likely to have access to a variety of strategies and insider information otherwise not accessible to outsiders (Lamb, 2017). Interlock is also considered as a communication channel knowledge transfer between companies (Shropshire, 2010).

Therefore, the interlock relationships can create cooperation among companies where there is exchange of information and knowledge so that companies can increase competitive advantage and be able to face market competition. The impact of competitive advantages that will affect the performance of a company, the better a company's board of directors to run the policy, the higher chances of companies in improving the performance of the company (Prihandoko, 2018). Interlock have an impact on the climate of business competition, this practice raises a policy decision or control over the company to create a strategy. This strategy may be setting the amount of production, procedures for marketing, pricing, allocation, and a variety of other strategies that benefit both companies.

Borgatti and Foster, 2003 revealed that the interlock the board of directors can be a medium for companies to reduce uncertainty and facilitate the search for references to resources. The board of directors has an important role in the company, which the board of directors authorized the management of existing resources in the company. Companies that interlock can benefit from each resource that is supported by the empirical results where total assets of companies doing interlock of 20.226.692 higher than companies that do not interlock amounted to 16.267.749. The total value of assets of the larger makes the com- pany has corporate performance is proxied by the ROA ratio is greater as well. So that interlock will produce an average of the high performance of the company in accordance with research Pombo and Gutiérrez (2011) and Prihandoko (2018) where concurrent positions as a means to access and exchange information to ensure the efficient activities of the company.

\section{CONCLUSION AND RECOMMENDATION}

Based on the results of research and discussion on the performance of the company's interlock proxied by ROA in public companies listed on the Indonesian Stock Exchange (BEI) in the period 2008-2017. Results of research on corporate performance interlock consistent with the hypothesis that has been developed is there difference in the average performance of the company on the companies that interlock and do not interlock. It shows that there are on average higher corporate performance in companies that perform interlock than companies that do not perform interlock where it is not in accordance with agency theory.

Firm that do interlock enables directors to gain access elsewhere. Relations interlock can create cooperation among companies where there is exchange of information and knowledge so that companies can increase competitive advantage and be able to face market competition. The board of directors has an important role in the company, where the board has a license in the management of existing resources in the company. Therefore, the company can benefit from each interlock resources. This is evidenced by the average total assets of companies doing interlock higher than the average total assets in companies that do not interlock.

The limitations in this study is the value of the coefficient of determination $12.4 \%$, which means the degree of variation of the variable performance of the company is able to be explained by the variable interlock and size of the company. The rest is equal to $87.6 \%$ explained by other variables outside the model. The future researchers can further develop research on the interlock and the firm performance with the performance of other companies proxy variables such as proxy Return on Equity (ROE), Tobin's Q or Price to Book Value (PBV).

\section{REFERENCES}

Ahmar, N., Pujiati, D., \& Nahumury, J. (2016). Satu Dekade Investigasi Interlocking Directorate: 
sebuah Model Deteksi Praktik Monopoli? Jurnal Akuntansi Multiparadigma JAMAL.

Alghifari, E. S. (2014). Pengaruh Risiko Sistematis terhadap Kinerja Perusahaan dan Implikasinya pada Nilai Perusahaan (Studi pada Perusahaan Food and Beverage di Bursa Efek Indonesia Tahun 2007-2011). Jurnal Ilmu Manajemen dan Bisnis, 5(1), 1-16.

Banks, E. (2004). Corporate Governance: Financial Responsibility, Controls and Ethics. Palgrave Macmillan.

Borgatti, S. P., \& Foster, P. C. (2003). The Network Paradigm in Organizational Research: a Review and Typology. Journal of Management, 29(6), 991-1013.

Davis, G. F. (1996). The Significance of Board Interlocks for Corporate Governance. Scholarly Research and Theory Papers, 4(3), 154-159.

De, B. (2003). The Incidence and Performance Effects of Interlocking Directorates in Emerging Market Business Groups: Evidence from India. Research Paper in Economics.

Ghozali, Imam \& Ratmono, D. (2013). No Title. FEB Universitas Diponegoro.

Gustina, D. L., \& Wijayanto, A. (2015). Analisis Rasio Keuangan dalam Memprediksi Perubahan Laba. Management Analysis Journal, 4(2), 120128.

Hamdan, A. (2018). Board Interlocking and Firm Performance: the Role of Foreign Ownership in Saudi Arabia. International Journal of Managerial Finance.

Haryanto, S. (2014). Identifikasi Ekspektasi Investor Melalui Kebijakan Struktur Modal, Profitabilitas, Ukuran Perusahaan dan GCPI. Mamika Manajemen, 5(2), 183-199.

Hermalin, B. E., \& Weisbach, M. S. (2003). Boards of Directors as an Endogenously Determined Institution: a Survey of the Economic Literature, (April), 7-26.

Jensen, \& Meckling. (1976). Theory of the Firm: Managerial Behavior, Agency Costs and Ownership Structure. Journal of Financial Economics, 3, 305-360.

Kaczmarek, S., Kimino, S., \& Pye, A. (2012). Interlocking Directorships and Firm Performance in Highly Regulated Sectors : the Moderating Impact of Board Diversity. Journal of Management \& Governance.

Keuangan, otoritas jasa. (n.d.). Roadmap Tata Kelola Perusahaan Indonesia.

Komisi Pengawas Persaingan Usaha Republik Indonesia. (2009). Perkom KPPU Nomor 07 Tahun 2009 tentang Pedoman Jabatan Rangkap Sesuai Ketentuan Pasal 26 UU No 5 Tahun 1999 Tentang Larangan Praktek Monopoli dan Persaingan Usaha Tidak Sehat.

Lamb, N. H. (2017). Does the Number of Interlocking Directors Influence a Firm's Financial Performance? an Exploratory Meta-Analysis. American Journal of Management Vol., 17(1998), 47-57.

Mizruchi, M. S. (1996). What Do Interlock Do? an
Analysis, Critique, and Assessment of Research on Interlocking Directorates. Annual Reviewing of Sociology, 22(271).

Muliawati, S., \& Khoiruddin, M. (2015). Faktor-Faktor Penentu Profitabilitas Bank Syariah di Indonesia. Management Analysis Journal, 3(2), 1-6.

Nam, H. J., \& An, Y. (2018). The Effect of Interlocking Directors Network on Firm Value and Performance: Evidence from Korean-Listed Firms. Global Economic Review, 47(2), 151-173.

Non, Marielle C \& Franses, P. H. (2007). Interlocking Boards and Firm Performance : Evidence from a New Panel Database. Tinbergen Institute Discussion Paper.

Nugraha, A. A. (2013). Analisis Pengaruh Struktur Modal terhadap Kinerja Perusahaan yang Tergabung dalam Indeks Kompas 100. Management Analysis Journal, 2(1), 1-7.

Pombo, C., \& Gutiérrez, L. H. (2011). Journal of Economics and Business Outside Directors, Board Interlocks and Firm Performance: Empirical Evidence from Colombian Business Groups. Journal of Economics and Business, 63(4), 251277.

Prihandoko, N. D. (2018). Pengaruh Rangkap Jabatan (Interlocking Directorate) dan Proporsi Dewan Komisaris Independen terhadap Kinerja Perusahaan dan Kinerja Pasar pada Perusahaan Manufaktur di Bursa Efek Indonesia. Stieykpn.

Rahmawati, D. \&, \& Khoiruddin, M. (2017). Pengaruh Corporate Governance dan Kinerja Keuangan Dalam Memprediksi Kondisi Financial Distress. Management Analysis Journal, 6(1).

Ridhloah, S. (2010). Faktor Penentu Struktur Modal: Studi Empirik pada Perusahaan Multifinansial. Jurnal Dinamika Manajemen, 1(2), 144-153.

Ross, A. (1973). The Economic the Theory of Agency: Principal's Problem. Decision Making Under Uncertainty Y, 63 No. 2.

Roudaki, J., \& Bhuiyan, M. B. U. (2015). Interlocking Directorship in New Zealand Interlocking Directorship in New Zealand. Australasian Accounting, Bussiness and Finance Journal, 9(3), 4558 .

Safitri \&Yulianto, R. D. S. \& A. (2015). Pengaruh Kinerja Keuangan Perusahaan terhadap Return Total Saham pada Perusahaan Manufaktur yang Terdaftar di Bursa Efek Indonesia. Management Analysis Journal, 4(1).

Saidin, N., Malek, M., \& Saidin, S. F. (2013). The Impact of Interlocking Directorates on Corporate Performance of Bursa Malaysia Listed Companies. Pertanika Journal of Social Science and Humanities, (September 2015).

Seftianne, \& Handayani, R. (2011). Faktor-faktor yang Mempengaruhi Struktur Modal pada Perusahaan Publik Sektor Manufaktur. Jurnal Bisnis Dan Akuntansi, Volume 13(1), H1m 39-56.

Shropshire, C. (2010). The Role of The Interlocking Director and Board Receptivity in The Diffusion of Practices. Academy of Management Review, 35(2), 246-264. 
Wardoyo \& Veronica, T. M. (2013). Pengaruh Good Corporate Governance, Corporate Social Responsibility \& Kinerja Keuangan terhadap Nilai Perusahaan. Jurnal Dinamika Manajemen, 4(2), 132-149.

Wijayanto, A. (2010). Analisis Pengaruh ROA, EPS, Financial Leverage, Proceed Terhadap Initial Return. Jurnal Dinamika Manajemen, 1(1), 6878.

Yulianto, A. (2013). Keputusan Struktur Modal dan Kebijakan Deviden sebagai Mekanisme Men- gurangi Masalah Keagenan. Jurnal Dinamika Manajemen, 4(2), 161-179. Yulianto, A., Suhadak, Darminto, \& Handayani, siti ragil. (2014). The Role of Corporate Governance, Dividend Policy, and Capital Structure on Ownership Structure toward the Firm Value. European Journal of Business and Management, 6(8), 134-141.

Yulianto, A., Witiastuti, R. S., \& Ardiansari, A. (2018). Trade-off or Pecking Order Theory in Indonesia. Eouropean Journal of Business and Management, 10(30), 2010-2012. 